\title{
Looking back at the quarter century of Kinanthropology. Unde venis et quo vadis Kinanthropology
}

\author{
Marek Waic
}

\author{
Department of Kinanthropology and Humanities, Faculty of Physical Education and Sport, \\ Charles University, Prague, Czech Republic \\ waic@ftvs.cuni.cz
}

\begin{abstract}
The study is aimed at dealing with the development of kinanthropology as a science discipline, and scientific beginnings related to the area of movement at the end of the 19th century. In addition, the study reminds us of the contributions of František Smotlacha to the development of these sciences. Further, it is devoted to the 90's of the last century when kinanthropology was established as a discipline of postgraduate studies and an associated habilitation discipline.
\end{abstract}

\section{KEYWORDS}

kinesis; anthropos; human movement studies; Charles University; physical education

DOI

10.14712/23366052.2019.1

(c) 2019 The Author. This is an open-access article distributed under the terms of the Creative Commons Attribution License (http://creativecommons.org/licenses/by/4.0), which permits unrestricted use, distribution, and reproduction in any medium, provided the original author and source are credited. 


\section{INTRODUCTION}

In the first issue of the Journal of Physical Education of Youth in 1992, we find a short entry titled "Kinanthropology has Entered the World." This entry reflected the fact that Kinanthropology was accredited as a postgraduate course at the Faculty of Physical Education and Sport (FTVS) at Charles University in 1991 and subsequently became a field for habilitation.

In this report we read: "The word kinanthropology is the etymological combination of three Greek words kinesis (to move), anthropos (human) and logos (word). The term logos is usually the second part of a composite of words describing an expert in the area that is expressed in the first part" (Physical Education of the Youth, 1992, 58(1), p. 1). Kinanthropology and kinanthropologists were born.

Kinanthropology, however, did not rise out of nothing. Still, its conception was a significant milestone in the evolution of the study of human movement in the Czech lands. Finding the starting point is not easy. If kinanthropology was born at Charles University, then let's focus on academia. In February 1882, the Charles-Ferdinand University ${ }^{1}$ was divided into Czech and German parts, or rather, into Czech and German universities. Ten years later, by the decree of Ministry of Cultus and Instruction, Czech and German Educational Courses for Physical Education Teachers of Secondary Schools and Teachers' Institutions were established. In 1906, the Czech course was affiliated with the Institute of Anatomy of the Czech Medical Faculty. Prof. Dr. Jan Jánošík, ${ }^{2}$ who was replaced by prof. Dr. Karel Weigner ${ }^{3}$ in 1927, was appointed the course director. A tradition was maintained that the courses was headed by a professor of anatomy and a director of the Institute of Anatomy of the Medical Faculty of Charles University. The lectures and seminars were conducted in three areas: 1. Practical physical education, 2. Theory, history, assignments, tools and system of physical education, 3. Anatomy, physiology, basics of health and nutrition sciences. ${ }^{4}$ Even before the First World War, the lectures could easily be divided into three specific fields of social-sciences, biomedical sciences and sport. The mission of the course was primarily educational, but the lectures were led by the best specialists in these fields who draw upon the latest scientific knowledge of the times and applied them to human movement.

1 The Austrian Emperor Ferdinand III participated in the reform of the university after he took Carolinum from the Jesuits in 1638 and restored independent law and medical studies under the imperial protector. In 1654, the emperor enacted the agreement of all parties to create one Charles-Ferdinand University with four faculties, while the Faculty of Philosophy and Theology remained in the administration of the Jesuits; the Archbishop was confirmed as Chancellor, although the role was in practice performed by the rector. The Prague university bore the abovementioned name until the establishment of Czechoslovakia.

2 Prof. Dr. Jan Jánošík (1856-1927), a founder of the Czech anatomy; between 1910 and 1911 a rector of Charles-Ferdinand University.

3 Prof. Dr. Karel Weigner (1874-1937), a pupil of professor Jánošík, who replaced him in the role of the director of the Institute of Anatomy; between 1936 and 1937 a rector of Charles University.

4 Dějiny Univerzity Karlovy, IV, 1918-1990. Prague: Karolinum, 543 p. 
The next step in the emancipation of the study of movement was the habilitation of František Smotlacha. František Smotlacha was a graduate of the course and studied Natural Sciences at the Faculty of Philosophy. ${ }^{5}$ In 1907, he passed a state exam from "physical education for secondary schools" and, in 1909 and 1910, from mathematics, physics and natural science. In 1911, František Smotlacha defended his dissertation thesis on mycology and passed a rigorous examination in zoology, botany and philosophy and became a Doctor of Philosophy. In July 1914, Dr. Smotlacha received the "Voluntary Supplement to First Approbation," by passing an exam (according to the new exam rules) in swimming, first aid, fencing, games and track and field. In 1924, Smotlacha was authorized to establish an Institute of Physical Education and Sport for the students of Charles University which was affiliated with the Faculty of Science. In 1930, Dr. Smotlacha presented his thesis on "Biological basis of humans interest in climbing and hanging" before the faculty of the Faculty of Science of Charles University and became an associate professor in the field of "methodology and systems of physical education" (Waic, 2011, p. 54). By this, the study of movement had been de facto recognized at Charles University.

In 1927, František Smotlacha started publishing a magazine called New Physical Education, a Journal for Physical Education, Games, Sports, Scouting and Research. It was the first periodical in the Czech lands which had an ambition to publish a variety of scientific research from various fields of study on human movement, to popularize them and thus enrich the teaching of physical education at secondary schools. The pages of New Physical Education provided new space for discussion on the further direction of physical education sciences:

The direction of the journal is defined by the progress of physical education and education as such and the progress of sports, scouting as well as gainful physical work. It will discuss questions from the field of study of human as a subject of physical education, or as a practitioner of physical education, sports, scouting and gainful employment, i.e. biology (anthropology), psychology (pedopsychology) and sociology, as well as from the field of study of education: hygiene, eugenics, economics, logic, ethics and aesthetics. These sciences determine the direction of education, and hence physical education, and are also important sciences for the appreciation of physical education, sports, games, scouting, gainful employment and all their methods (Nová tělesná výchova, 1927, 1(1), p. 1).

On November 17, 1939, the Nazi occupiers closed the doors of Czech universities. After the liberation of Czechoslovakia in 1945, the Institute for the Education of Physical Education Teachers at Charles University was established, replacing the Educational Course, but the modest conditions in which it operated and frequent organizational changes that accompanied the physical education courses, did not favour the development of the study of human movement.

The Government Decree from 7 April 1953 established the Institute of Physical Education and Sport (ITVS) and the Research Institute of Physical Education and the Centre of Physical Education began to be created within the ITVS. The institutional establishment of the Research Institute of Physical Education had certainly been a sig-

5 An independent Faculty of Science was established in 1920. 
nificant contribution to the development of the study of human movement. The actual benefit to this development is difficult to evaluate, and its assessment would require a deeper analysis, in which it would be necessary to separate the powerful ideological ballast from rational knowledge in the professional publications of that time.

The gradual loosening of the Communist nomenclature control over all areas of society, including the study of movement, created an environment in which it was possible to discuss the constitution of an independent study of human movement and its exit from the field of physical education pedagogy. In 1967, Professor Stanislav Čelikovský (from 1962 to 1973 Vice-Dean for Science of FTVS) initiated an international conference at the Faculty of Physical Education and Sport of Charles University, where participants discussed the establishment of the scientific discipline of human movement. Although they were not successful in their venture, Stanislav Čelikovský and his pupils Rudolf Kovár and Petr Blahuš managed to establish one of the fundamental disciplines of the study of movement - anthropomotorics. The normalization had put a stop to the establishment of an independent study of human movement. But that did not mean the research stopped too. The Communist normalizers focused mainly on sport humanities, but in other disciplines several empirical researches and experiments were carried out and yielded many interesting results. It is not for the historian to assess whether some of them have been wrongly forgotten, but I dare to say that literature and periodicals from the 1970s and 1980s should not be forgotten, so that we do not discover what was already discovered, which is a phenomenon that is not unknown in the history of science.

The fall of the communist regime in Czechoslovakia brought new opportunity to the Faculty of Physical Education and Sport at Charles University to freely discuss the establishment of a field of study that would focus on movement. In this discussion, a generation of experts who received the highest scientific accolades, spoke the loudest. These were Petr Blahuš, Václav Hošek, Rudolf Kovář and Pavel Slepička who were appointed professors at the turn of the 1980s and the first half of the 1990s. It was this "strong generation" that stood at the birth of the science of Kinanthropology.

In the early 1990s, the Department of Fundamentals of Kinanthropology was established at FTVS, headed by prof. PhDr. Zdeněk Teplý, DrSc. In October 1991, the Kinanthropology was accredited by the Accreditation Commission as a postgraduate doctoral degree program and subsequently as the field of habilitation. A Kinanthropological Scientific Society was established at the conference on Kinanthropology, held during the celebrations of the 40th anniversary of the Institute of Physical Education and Sport (Blahuš, 1993).

The new field of study was given an institutional framework, but its content had to be clarified, which the participants of the conference attempted. The first definitions of the discipline also emerged. Also applicable to the present is the one from Petr Blahuš: "The subject of Kinanthropology is human intentional physical activity and its relation to the development of man as a biopsychosocial individual" (Blahuš, Česká kinantropologická společnost. Not dated).

In his contribution at the "founding" conference Lubomír Dobrý said that Kinanthropology: "implicitly contains requirement to specify in each individual field of the broad kinanthropological spectrum what is presented here in a general form, and thus to express a relation of the particular and special to the general" (Dobrý, 1992, p. 2). 
He thus initiated a discussion on the structure of sub-fields of Kinanthropology, a discussion which is still alive to this day.

We may ask ourselves a somewhat heretical question whether the "kinanthropological" journey that started at the beginning of the 1990s is really the right one, or whether, for the area where our research and educational efforts are directed, we should not have chosen a different collective label, such as studies of sport. But it would remain only hypothetical because it is too late to return. Kinanthropology as a term describing the study of human movement has already been established and is generally accepted not only by the professional kinanthropological community but also by experts from other fields of science. In the institutional framework of education and pedagogical-scientific qualifications, Kinanthropology has also been already firmly established. This process was completed by the definition of educational areas in the amendment to the Higher Education Act of 2016, which included Physical Education - Kinanthropology, and within which the first study programs were accredited to our Faculty. Also, Biomedical and Social Science Kinanthropology were included in the system of internal evaluation of various disciplines fostered at Charles University.

The current assessment of the academic performance of academic institutions is based on the evaluation of atomized disciplines. Kinanthropology is an exception in this respect, which makes it unique, because it seeks to explore human movement in its interdependence and complexity. For example, the growing deficit in population's physical activity, especially in rich countries with developed infrastructure (including the Czech Republic), has mainly social causes with far-reaching health consequences. The kinanthropologists have tools to examine all the components of the process throughout the chain of mutually affecting causes and consequences and to look for ways to reverse this negative trend.

The only thing remaining is to wish Kinanthropology that it will avoid any pitfalls on its future path and to all researchers, who devote their time to this science, not only enough placements in the "top" science observed in the "quartiles," but above all, a lot of ingenuity in finding research topics which would bring them joy and which would actually develop knowledge of the human movement.

\section{REFERENCES}

Bečvář, J., Havránek, J., \& Pousta, Z. (1998). Dějiny Univerzity Karlovy. Prague: Karolinum. Blahuš, P. (1993). Kinantropologie na Univerzitě Karlově. Tělesná výchova mládeže, 59(7), $17-23$.

Dobrý, L. (1992). Potřeba kinantropologie. Tělesná výchova mládeže, 58(1), 1-4.

Nová tělesná výchova: list pro tělesnou výchovu, tělocvik, sport, hry, skauting a vědecké studium těchto oborů (1927). 1(1). Prague: Ústav tělesné výchovy, tělocviku a sportu.

Tělesná výchova mládeže: nezávislý list pro učitelstvo všech druhủ škol, kandidáty učitelství, tělocvičné a sportovni spolky, cvičitele a vychovatele mládeže (1992). Brno: Melantrich.

Waic, M. (2011). Zrození českého akademického sportu a František Smotlacha. Česká kinantropologie, 15(2), 49-58. 